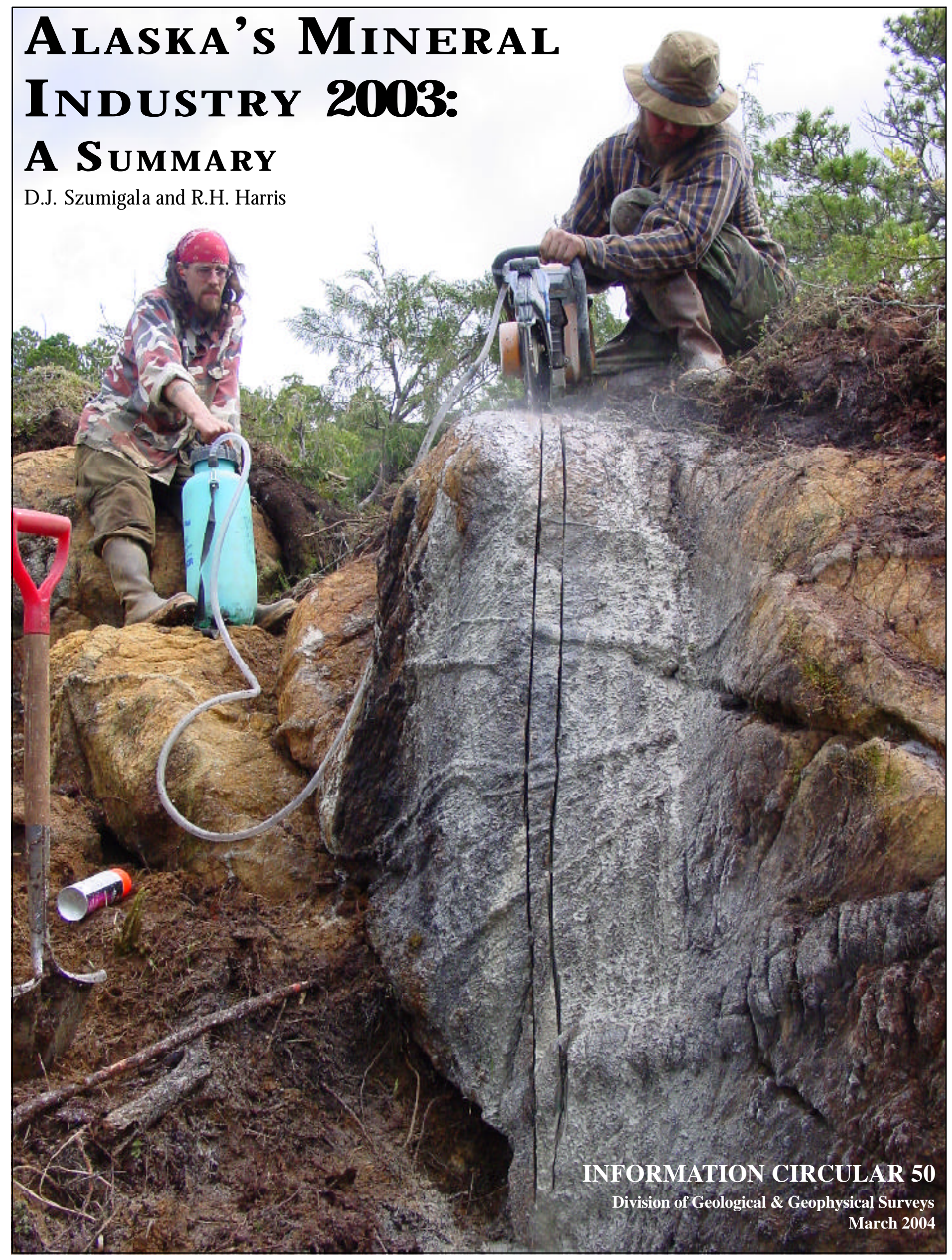




\title{
Alaska's Mineral Industry 2003: A Summary
}

\author{
by \\ D .J. Szumigala ${ }^{1}$ and R.H. Harris ${ }^{2}$
}

\section{INTRODUCTION}

This summary of Alaska's mineral industry activity for 2003 is made possible by information provided through press releases, annual reports, phone interviews, and replies to questionnaires mailed by the Alaska Division of Geological \& Geophysical Surveys (DGGS). The final report will be available later in the year after further compilation of information, particularly for placer mining and industrial minerals. This report is part of a cooperative venture between DGGS and the Division of Mining, Land, \& Water (DMLW) in the Department of Natural Resources (DNR) and the Division of Trade \& Development (DTD) in the Department of Community \& Economic Development (DCED). The estimates used in this summary are generally conservative due to incomplete data. This summary and data contained within it will be superceded by DGGS Special Report 58 to be published later in 2004.

The total value of the Alaska mineral industry is expected to be approximately $\$ 1.05$ billion for 2003 , the eighth straight year topping one billion dollars. Table 1 shows the estimated value of the mineral industry in Alaska per year between 1981 and 2003, as divided between exploration and development investments, and the gross value of the mineral products. These preliminary combined values totaled $\$ 1,017.1$ million in 2003 , compared with $\$ 1,073.3$ million in 2002. The low level of development investment (\$15.9 million) in 2003 compared with the $\$ 33.5$ million reported in 2002 was compounded by the decreased value of mineral products (\$980.3 million) in 2003 compared with $\$ 1,012.8$ million in 2002. Although lode metal mine production remained near 2002 levels, rising base- and precious metal prices increased the value of metals production by 2 percent compared to last year. The exploration investment of \$20.9 million in 2003 was significantly less than the $\$ 26.5$ million invested in 2002. Lackluster exploration activity can be attributed to late season availability of venture capital, continued weakness of the Canadian dollar, and attractive tax incentives for investors in Canadian based projects.
Table 1. Total value of the mineral industry in Alaska by year (in millions of dollars)

Exploration Development Production Total (expenditure) (expenditure) (value) (calculated)

\begin{tabular}{lrrrr}
1981 & 76.3 & 24.7 & 188.6 & 289.6 \\
1982 & 45.6 & 41.6 & 196.4 & 283.7 \\
1983 & 34.1 & 27.9 & 212.4 & 274.4 \\
1984 & 22.3 & 53.4 & 199.4 & 275.1 \\
1985 & 9.2 & 34.1 & 226.6 & 269.9 \\
1986 & 8.9 & 24.3 & 198.5 & 231.7 \\
1987 & 15.7 & 100.3 & 202.4 & 318.4 \\
1988 & 45.5 & 275.0 & 232.2 & 552.6 \\
1989 & 47.8 & 134.3 & 277.0 & 459.0 \\
1990 & 63.3 & 14.3 & 533.0 & 610.6 \\
1991 & 39.9 & 25.6 & 546.5 & 612.0 \\
1992 & 30.2 & 29.6 & 560.8 & 620.6 \\
1993 & 30.3 & 27.7 & 448.7 & 506.7 \\
1994 & 31.1 & 45.0 & 507.5 & 583.6 \\
1995 & 34.3 & 148.6 & 537.2 & 720.1 \\
1996 & 44.7 & 394.0 & 590.4 & $1,029.2$ \\
1997 & 57.8 & 168.4 & 936.2 & $1,162.4$ \\
1998 & 57.3 & 55.4 & 921.2 & $1,033.9$ \\
1999 & 52.3 & 33.8 & $1,032.9$ & $1,119.0$ \\
2000 & 34.9 & 141.7 & $1,106.4$ & $1,283.0$ \\
2001 & 23.8 & 81.2 & 917.3 & $1,022.3$ \\
2002 & 26.5 & 34.0 & $1,012.8$ & $1,073.3$ \\
2003 & 20.9 & 15.9 & 980.3 & $1,017.1$ \\
& & & & \\
TOTAL & $\mathbf{\$ 8 5 1 . 2}$ & $\mathbf{\$ 1 , 9 3 0 . 8}$ & $\mathbf{\$ 1 2 , 5 6 4 . 7}$ & $\mathbf{\$ 1 5 , 3 4 8 . 2}$ \\
\hline
\end{tabular}

SOURCE: Alaska's mineral industry reports published annually by DGGS.

Exploration during 2003 occurred across most regions of the state, with 70 percent of the exploration funds spent in southwestern and eastern Alaska. More than \$12 million was spent exploring on gold and associated precious-metal projects across the state. Several large projects, notably Northern Dynasty's Pebble copper-gold project in southwestern Alaska, Kinross Gold's Fairbanks mining district gold projects in the Interior, and Freegold VenturesLonmin's Union Bay platinum-nickel-copper project in southeastern Alaska accounted for most of the exploration expenditures and drill footage. 
Mining development projects in 2003 included lode projects at the Greens Creek Mine (silver-zinc-gold-lead) and Kensington (gold) project in southeastern Alaska, Donlin Creek (gold) in the southwestern region, Rock Creek (gold) in western Alaska, Pogo (gold) in the eastern interior region, and the Nolan Creek Placer (gold) project in northern Alaska. These projects consisted primarily of feasibility studies and permitting but included substantial drilling at Rock Creek, and underground development and drilling at Nolan Creek. The decline in development spending reflects a shift to feasibility studies and permitting at advanced exploration projects, deferred development spending at Red Dog due to weak zinc prices, and an emphasis on exploration for new resource at the Fort Knox Mine complex.

Greens Creek mine achieved record production for the second consecutive year while tons milled at Red Dog and Fort Knox decreased very slightly from robust 2002 levels. Placer gold production should be similar to 2002 production once final reports are received, while sand, gravel, rock, and other industrial materials may see a moderate decrease due to a decline in North Slope oil and gas activity and reduced statewide infrastructure projects.

\section{EMPLOYMENT}

Table 2 lists estimated employment in the Alaska mineral industry for the past 7 years. The total minerals industry employment in 2003 is estimated to be 2,496 full-timeequivalent jobs, a drop of about 328 jobs from the 2,824 jobs reported in 2002. With more complete data, the number of 2003 jobs is expected to rise but remain slightly lower than the 2002 levels. Most of the decline was in the development, exploration, and industrial minerals sectors.

\section{EXPLORATION}

Estimated exploration expenditures in Alaska during 2003 are approximately $\$ 21$ million, a $\$ 5.5$ million decrease compared to expenditures of \$26.5 million in 2002. Exploration expenditure values for 2003 are very preliminary at this time. The drop in expenditures is unclear, but likely due to a lack of venture capital early in 2003, midyear increases in metal prices but no time to readjust worldwide exploration spending by mining companies, a late start to some major projects with the majority of funds and work to be done in 2004, and several large projects in Alaska advancing from the exploration phase to the development phase in 2003. As in years past, most exploration funds, more than 70 percent, were derived from Canadian sources. Other reasons for low exploration funding from Canadian sources include late season availability of venture capital, continued weakness of the Canadian dollar, and attractive tax incentives for investors in Canadian based projects. The value of mineral exploration is still low compared to spending levels in the late 1980s through late 1990s. Exploration was conducted throughout Alaska, but the largest projects were in southwestern Alaska, eastern Interior Alaska, and southeastern Alaska. Several large projects, notably Northern Dynasty's Pebble copper-gold project in southwestern Alaska, Kinross Gold's Fairbanks mining district projects in the Interior, and Freegold Ventures-Lonmin's Union Bay platinum-nickel-copper project in southeastern Alaska, accounted for most of the exploration expenditures and exploration drill footage. Figure 1 shows the location of the most significant exploration projects in Alaska during 2003. Overall, one-third of the 2003 Alaska exploration expenditures were spent in southwestern Alaska and slightly more than one-third

Table 2. Estimated Alaska mine employment, 1997-2003 ${ }^{a}$

\begin{tabular}{|c|c|c|c|c|c|c|c|}
\hline & 1997 & 1998 & 1999 & 2000 & 2001 & 2002 & 2003 \\
\hline \multicolumn{8}{|l|}{ Gold/silver mining } \\
\hline Placer & 780 & 710 & 591 & 470 & 176 & 148 & 130 \\
\hline Lode & 415 & 345 & 296 & 274 & 337 & 413 & 400 \\
\hline Polymetallic & 230 & 275 & 275 & 275 & 275 & 262 & 265 \\
\hline Base metals & 478 & 466 & 549 & 556 & 559 & 580 & 575 \\
\hline Recreational & 270 & 255 & 240 & 250 & 210 & 180 & 175 \\
\hline Sand \& gravel & 700 & 658 & 590 & 603 & 556 & 702 & 575 \\
\hline Rock & 123 & 121 & 128 & 150 & 137 & 177 & 140 \\
\hline Coal & 118 & 128 & 121 & 121 & 121 & 100 & 65 \\
\hline Peat & 42 & 40 & 38 & 36 & 32 & 21 & 20 \\
\hline $\begin{array}{l}\text { Tin, jade, soapstone, } \\
\text { ceramics, platinum }\end{array}$ & 20 & 20 & 20 & 20 & 20 & 20 & 20 \\
\hline Mineral development & 409 & 177 & 135 & 345 & 333 & 135 & 70 \\
\hline Mineral exploration & 277 & 282 & 183 & 83 & 79 & 86 & 61 \\
\hline TOTAL & 3,862 & $\mathbf{3 , 4 7 7}$ & 3,166 & 3,183 & 2,835 & 2,824 & 2,496 \\
\hline
\end{tabular}

${ }^{\mathrm{a} C}$ Calculated on a 260-day work year. 
of the total was spent in the eastern interior region. Overall, the southwestern region saw a sharp reduction in activity. Gold remained the major exploration commodity, but exploration expenditures for gold dropped by approximately \$5 million from 2002 to 2003 (table 3). Base metal exploration expenditures also dropped significantly, while polymetallic exploration increased significantly higher than 2002 levels. Platinum-group-element exploration increased significantly from 2002 levels. Table 3 lists exploration expenditures by commodity.

\section{Northern Region}

Silverado Gold Mines and Tricon, its contract mining/ exploration company, continued placer and lode gold exploration at the Nolan property near Coldfoot and the Dalton Highway, specifically directed at the lode source of the Nolan placer gold deposits, including definition of placer gold targets. Lode gold areas of interest include the Solomon Shear and placer targets include the Treasure Chest area, the Nolan Creek Deep Channel, the Swede Channel, and Mary's Bench. An exploration program was started in early 2003 and directed at improving placer reserve definition and discovery of a lode source for the placer gold. The exploration effort consisted of geophysical data analysis, geochemical sampling and analysis, and exploration drilling of target areas. Lode gold exploration involved the analysis of geophysical, geochemical, and geological data provided by government mineral investigation efforts and publications and company records. This led to the definition of a resistivity-low anomaly trending northeasterly from about lower Smith Creek, across the west face of Smith Dome, through upper Archibald Creek, upper Fay Creek and into the Hammond River drainage. This anomaly suggested the presence of conductive minerals (sulfides) and a possible lode source of placer gold. Past geochemical sampling by the U.S. Bureau of Land Management showed anomalous gold and associated element values from the area. Tricon undertook a geochemical soil sampling program of the anomalous zone using handheld power augers. Nine lines of auger holes were laid out along the anomalous zone from near Fay Creek to south of Smith Creek; the lines were approximately $90^{\circ}$ to the orientation of the indicated shear zone. Soil samples were collected from a total of 290 auger holes and geochemical analytical results from these samples further confirmed that an anomalous geochemical target existed on or near the resistivity-low anomaly. This target has been named the Solomon Shear; the anomaly is suspected to be a linear zone (shear) created by a fault system running nearly parallel to Nolan Creek. This fractured zone is thought to have been a conduit for mineral-bearing fluid migration, and a host for mineral deposition. Thirty-six lode claims were staked on the Solomon Shear area during 2003 to ensure complete coverage of the zone.

A placer gold exploration and development-drilling program was undertaken during September and October to define the upper Nolan Creek gold resource and to explore the "Treasure Chest" zone. The Treasure Chest area was designated by the geological crew as applying to an area above Mary's Bench on the side of Smith Dome. The area is a very likely placer deposit target based on geological and geomorphologic interpretation. Twenty-seven

Figure 1. Projects shown on this map represent $\$ 19.3$ million of the $\$ 20.9$ million spent on exploration in Alaska during 2003.

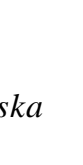

.
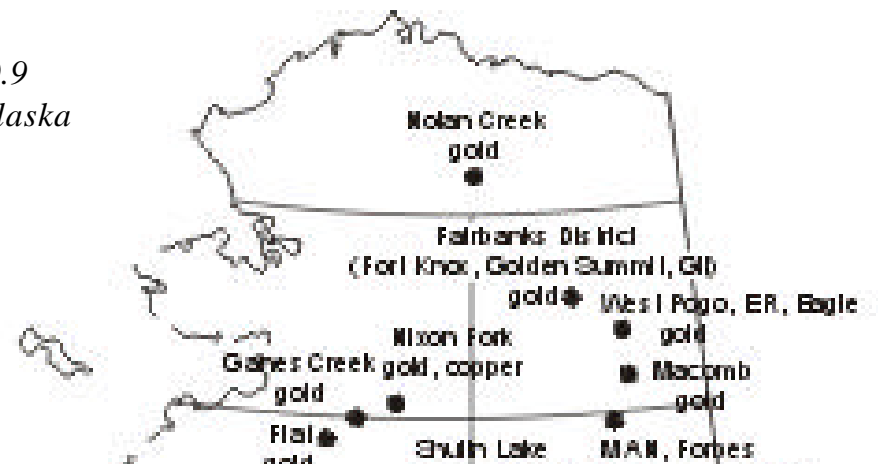

‥

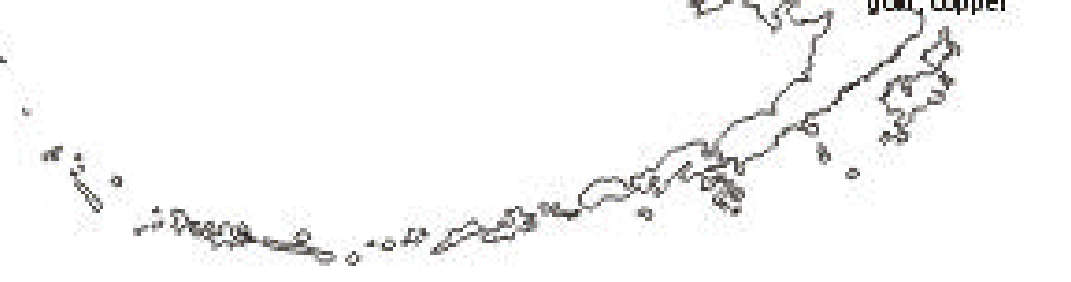

Greens Creek Bho
pobme illc

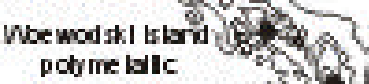

Urion Bay 3 के 3 है।

ridel; cqper; platrum 
Table 3. Reported exploration expenditures in Alaska by commodity, 1982-2003

\begin{tabular}{|c|c|c|c|c|c|c|c|}
\hline & $\begin{array}{c}\text { Base } \\
\text { metals }\end{array}$ & Polymetallic $^{\mathbf{a}}$ & $\begin{array}{l}\text { Precious } \\
\text { metals }\end{array}$ & $\begin{array}{c}\text { Industrial } \\
\text { minerals }\end{array}$ & $\begin{array}{c}\text { Coal } \\
\text { and peat }\end{array}$ & Otherb & Total \\
\hline 1982 & $\$ 31,757,900$ & N/A & $\$ 10,944,100$ & - & $\$ 2,900,000$ & $\$ \quad 15,300$ & $\$ 45,617,300$ \\
\hline 1983 & $9,758,760$ & N/A & $20,897,555$ & $2,068,300$ & $1,338,454$ & 70,000 & $34,133,069$ \\
\hline 1984 & $4,720,596$ & N/A & $14,948,554$ & 270,000 & $2,065,000$ & 279,500 & $22,283,650$ \\
\hline 1985 & $2,397,600$ & N/A & $6,482,400$ & - & 270,000 & -- & $9,150,000$ \\
\hline 1986 & $1,847,660$ & N/A & $6,107,084$ & 170,000 & 790,000 & -- & $8,914,744$ \\
\hline 1987 & $2,523,350$ & N/A & $11,743,711$ & 286,000 & $1,150,000$ & 31,000 & $15,734,061$ \\
\hline 1988 & $1,208,000$ & N/A & $41,370,600$ & 160,200 & $2,730,000$ & - & $45,468,800$ \\
\hline 1989 & $3,503,000$ & N/A & $43,205,300$ & 125,000 & 924,296 & 5,000 & $47,762,596$ \\
\hline 1990 & $5,282,200$ & N/A & $57,185,394$ & 370,000 & 321,000 & 97,000 & $63,255,594$ \\
\hline 1991 & $4,789,500$ & N/A & $34,422,039$ & 92,000 & 603,000 & 2,000 & $39,908,539$ \\
\hline 1992 & $1,116,000$ & $3,560,000$ & $25,083,000$ & 25,000 & 425,000 & - - & $30,209,000$ \\
\hline 1993 & 910,000 & $5,676,743$ & $23,382,246$ & 163,500 & - & 125,000 & $30,257,489$ \\
\hline 1994 & 600,000 & $8,099,054$ & $18,815,560$ & 225,000 & $2,554,000$ & 810,000 & $31,103,614$ \\
\hline 1995 & $2,770,000$ & $10,550,000$ & $20,883,100$ & 100,000 & - - & 3,000 & $34,306,100$ \\
\hline 1996 & $1,100,000$ & $11,983,364$ & $31,238,600$ & 400,000 & - & -- & $44,721,964$ \\
\hline 1997 & $1,700,000$ & $22,347,000$ & $32,960,500$ & 80,000 & 720,000 & - & $\mathbf{5 7 , 8 0 7 , 5 0 0}$ \\
\hline 1998 & $1,000,000$ & $13,727,000$ & $42,441,000$ & 12,000 & 87,000 & - - & $57,267,000$ \\
\hline 1999 & $3,869,000$ & $3,168,000$ & $44,891,000$ & 1,000 & - - & 410,000 & $52,339,000$ \\
\hline 2000 & $8,545,000$ & $3,933,000$ & $21,579,000$ & 58,500 & - & 736,100 & $34,851,600$ \\
\hline 2001 & $4,810,000$ & $1,977,000$ & $15,820,000$ & 50,000 & 10,000 & $1,106,000$ & $23,773,000$ \\
\hline 2002 & $1,700,000$ & $5,162,000$ & $17,342,000^{\mathrm{c}}$ & 185,000 & - & $2,113,000$ & $26,502,000$ \\
\hline 2003 & 223,000 & $7,376,000$ & $12,780,000$ & -- & -- & 464,000 & $20,900,000$ \\
\hline TOTAL & $\$ 96,131,566$ & $\$ 97,559,161$ & $\$ 554,522,743$ & $\$ 4,841,500$ & $\$ 16,887,750$ & $\$ 6,266,900$ & $\$ 776,266,620$ \\
\hline
\end{tabular}

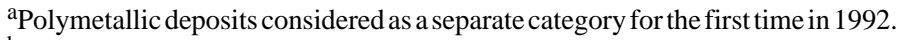

bIncludes diamonds and tantalum.

${ }^{\mathrm{c}}$ Approximately $\$ 2.3 \mathrm{M}$ spent on platinum-group-elementexploration during 2003 (\$2M in 2001, $\$ 640,00$ in 2002 ).

$\mathrm{N} / \mathrm{A}=$ Not available.

- - Notreported.

holes were drilled on upper Nolan Creek and defined an inferred resource of placer gold. An additional 27 holes were drilled in the Treasure Chest area. One hole returned a good mineralized intercept with significant amounts of stibnite, indicating the presence of a vein source in the area. A hard rock (vein) drilling program was laid out and commissioned during December. This drilling program is intended to test for the presence of vein or shear zone mineralization in the Solomon Shear.

\section{Western Region}

Late in 2002, St Andrew acquired a 51 percent interest in Mystery Creek Resources, which has an option to acquire a 100 percent interest in the historic Nixon Fork gold-copper mine near McGrath. Nixon Fork is a former high-grade (1 ounce per ton) gold producer with gold resources of approximately 190,000 ounces. The Nixon Fork gold mine consists of a 140-ton-per-day mill, workshops, offices, camp facilities, landing strip, power generation facilities, and associated mining equipment. St Andrews released a pre-feasibility study for the Nixon Fork project that describes the exploration and development activities and the estimated capital expenditure of $\$ 8,938,000$ over a 30-month period to place the Nixon Fork property into production at a rate of 58,000 tons gold per year. Gold production is estimated to commence in the second half of 2004 at an annualized rate of 50,000 ounces of gold, approximately 500,000 pounds of copper, and byproduct silver. Estimated cash costs are $\$ 180$ per ounce. Capital costs are projected to be $\$ 7.5$ million, with payback in 1.5 years, based on a gold price of $\$ 325$ per ounce. St. Andrews' partner, Geoinformatics Exploration Alaska Ltd., compiled and validated a complete geological database for the Nixon Fork and surrounding areas. The data was used to create a revised geologic model of the mineralization and to identify additional drill targets. Toward the end of the year a 450-foot development drift was driven from the Crystal decline for the purpose of underground drilling to explore and expand known gold resources at the mine. This drilling was begun in January 2004, targeting additional resources on known mineralized zones. All other work at Nixon Fork in 2003 was directed toward permitting and re-commissioning the camp and equipment.

Altar Resources and subsidiary Royal Pretoria continued exploration on their gold prospects, with work north of Nome and in the Council area. Rio Fortuna dropped 
their option on Altar's Full Auto property and conducted minor exploration on the Divide property.

Full Metal Minerals signed a joint-venture agreement with Clark-Wiltz Mining on the Ganes Creek gold property. The exploration target is the bedrock source for one of Alaska's most productive placer gold producing streams, and common large gold-quartz nuggets. Full Metal completed an initial surface mapping and sampling program, focusing on a two- to three-square-mile area.

DGGS released maps and results from a 618-squaremile geophysical survey in the Council area of the Seward Peninsula. Fieldwork including geologic mapping is planned for 2004.

\section{Eastern Interior Region}

Kinross Gold Corp. continued exploration in the Fairbanks mining district with extensive drilling around the Fort Knox and True North gold deposits. A mix of diamond and reverse-circulation drilling at True North continued throughout the year to focus on the conversion of resources to reserves and to outline the limits of mineralization. Kinross also conducted exploration, mainly drilling, at the Ryan Lode, Gil, and NOAA (or Dark Hollow) properties. Work at the Gil property, held jointly with Teryl Resources, also was designed to gauge the feasibility of mining this gold resource as another satellite deposit for the Fort Knox Mine complex.

Teryl Resources Corp. planned to conduct an exploration and drilling program in early January 2003 on its 100-percent-owned Westridge property and its 50 percent option from Linux Wizardry Systems Inc. on the Fish Creek property, both in the Fairbanks District. Teryl discovered gold mineralization at the Old Glory prospect on the Westridge property with mineralization in rock and soil samples. They also completed 1,000 feet of trenching on the Westridge property, with rock samples from highly oxidized shear zones in sericitized granodiorite and schist containing up to 0.3 ounces per ton gold associated with anomalous arsenic and bismuth. Sampling also occurred on the company's Black Dome prospect.

Freegold Ventures Ltd. (Freegold) announced a jointventure agreement with Meridian Gold Inc. on the Golden Summit project on Cleary Summit in the Fairbanks mining district. Freegold had drilled three diamond core holes in early 2003 near the Cleary Hill mine area of this property and confirmed the presence of a wide, lower-grade gold system hosted by quartz veins and stockwork zones. Previous drilling and surface exploration work had encountered high-grade gold mineralization hosted in quartz veins similar to those encountered in mining at the Cleary Hill Mine and 64 feet grading 0.138 ounces per ton gold in drillhole CHD00-1. Freegold also holds the Rob project area, covering historic gold mines east of the Pogo property, and has an option on the Rainbow Hill gold project.
AngloGold USA and partner Rimfire Minerals conducted exploration on the ER and Eagle gold projects in the Goodpaster area just west of the Pogo gold property. Work on the ER property resulted in drilling 7,000 feet of core in six holes centered over a large gold-in-soil anomaly with coincident arsenic, bismuth, and antimony anomalies along a contact between a Cretaceous intrusion and metamorphic country rocks. Drill results included more than 24 narrow intercepts with significant gold mineralization. Gold mineralization is hosted in Pogo-style quartz-sulfide veins with sericite and pyrite alteration and some vein breccias. At the Eagle property, AngloGold conducted additional soil sampling to follow up favorable soil results obtained in 2002. Workers investigated an intrusive contact on the east side of the property and four discrete gold-arsenic-bismuth-antimony-tungsten anomalies have been found over a 2-mile by 1-mile area. Rock chip samples from the area sometimes are altered and contain sulfide-bearing quartz veinlets. One rock sample contained 0.25 ounces per ton gold.

St. Andrews Goldfield Ltd. announced that it had acquired the Uncle Sam project in the Richardson district from Kennecott Exploration. The company must spend $\$ 250,000$ on the project over 5 years and Kennecott retains a 2.5 percent net smelter returns production royalty. Gold mineralization previously identified by Kennecott is predominantly shear hosted in the metamorphic country rock with additional local zones of hydrothermal breccia and sulfide veining. St. Andrews has a 45 percent interest in Geoinformatics Exploration Ltd., a technology based exploration company. Geoinformatics reinterpreted existing data at the Uncle Sam property, made a first pass three-dimensional model of structures intersected by previous drilling, and completed a geochemical and structural comparison of mineralized zones at the Uncle Sam property with published work on the Pogo deposit. Geoinformatics is currently developing a strategy for further exploration.

Geologix Explorations completed initial exploration at its Macomb gold prospect in the northern Alaska Range near Tok. Geophysical work and soil geochemical surveys identified likely gold targets and four drill holes were completed. Three diamond drill holes were unable to penetrate glacial till overburden that is at least 400 feet thick. The fourth drill hole tested a lower priority target and indicated sporadic low-level gold values scattered throughout a 50-foot-wide altered and faulted structural zone.

Usibelli Coal Mine Inc. explored their coal leases on Jumbo Dome, approximately 9 miles north of the Two Bull Ridge mine. Usibelli opened two large trenches and took two large bulk samples of coal from three coal seams. Analyses of the coal indicated very good quality, with approximately 4 percent ash content and 0.11 percent sulfur. These results are encouraging for the proposed Emma 
Creek Energy Project, a mine-mouth coal fueled power plant envisioned in the Jumbo Dome area.

\section{Southcentral Region}

Nevada Star Resources Inc. continued to explore the MAN property near Tangle Lakes and the Denali Highway with ground geophysical and soil geochemical surveys. Nevada Star drilled the Fish Lake Complex portion of the property where platinum and palladium mineralization has been discovered along with nickel and copper sulfides associated with mafic to ultramafic intrusions. Encouraging drilling results found semi-massive sulfide mineralization with platinum, palladium, and nickel mineralization, with the best intercept being 9 feet containing 0.03 ounces platinum per ton, 0.03 ounces palladium per ton, and 0.3319 percent nickel. In mid-December, Nevada Star announced a letter of intent with Anglo American Exploration Ltd. for approximately 50 percent of the MAN project area. DGGS, with funding from BLM, released geophysical maps and results from a 603-square-mile geophysical survey over ultramafic intrusions centered on the MAN property. The geophysical results spurred a claim staking rush that ultimately covered more than 80 square miles.

Golconda Resources continued exploration on the Shulin Lake diamond property in southcentral Alaska near Talkeetna. In September, the Shulin Lake Joint Venture drilled two holes into a complex circular structure visible on a satellite photo. This structure has a diameter of about $2 \mathrm{~km}$. The holes intersected a volcanic sequence of sandy tuffs and fine ash, indicating that this feature is most likely a volcanic center and the source of the diamond indicator minerals and micro-diamonds found in earlier programs. Indicator minerals selected from these two holes show a chemical composition similar to eclogitic minerals found in lamproitic environments elsewhere. The joint venture plans to drill ten holes for a total of 3,000 feet to test different areas of this circular structure in an effort to intersect volcanic rocks with higher olivine content that possess the greatest diamond potential. The drilling is scheduled for the second half of March 2004.

Western Warrior Resources Inc. concluded an exploration program, including drilling a total of 4,855 feet in six core holes, at the Cliff Gold Mine property close to Valdez, Alaska. The Cliff Mine produced a total of 51,740 ounces of gold from 29,695 short tons milled between 1910 and 1942, for an average recovered grade of 1.74 ounces of gold per ton. Prior to the 2003 drill program no exploration diamond drilling had been conducted at the property. The drill program was successful in intersecting the previously mined vein structures and in determining the geometry of several vein structures. Additionally, a distinct geochemical zoning or signature about the auriferous vein structures has been observed. The vein structure ge- ometry and geochemical signature provide significant data that will be utilized in the next phase of exploration at the property.

Mines Trust Co. explored the Golden Zone property with 1,000 feet of trenching in the Long Creek area about 1.5 miles south of the Golden Zone breccia pipe. Soil and rock samples were also collected, but no results were announced.

\section{Southwestern Region}

The Donlin Creek gold project dominated Alaska's exploration sector over the past several years and is now in the feasibility (development) phase. A new resource announced in late 2002 increased inferred gold resources by nearly 40 percent to 14.8 million ounces grading 0.102 ounces per ton, with a measured and indicated resource of 8.3 million ounces of gold grading 0.102 ounces per ton, using a 0.058 ounce per ton gold cut-off grade. The Donlin Creek deposit is ranked as the 22nd largest gold deposit in the world with 23 million ounces of gold resources. Placer Dome Inc. exercised its back-in right to earn a 70 percent ownership of the Donlin Creek project, and feasibility and engineering studies are underway. The current timetable, assuming a positive feasibility study, would have production begin in 2009 or 2010.

The Pebble property near Iliamna in southwestern Alaska was Alaska's largest exploration project in 2003. Northern Dynasty Minerals completed more than 72,000 feet of core drilling on this copper-gold porphyry to confirm, delineate, and extend higher-grade areas of the Pebble deposit. Based on an independent mineral resource estimate by Norwest Corp., Northern Dynasty announced in January 2004 that the Pebble deposit contains 26.5 million ounces of gold and 16.5 billion pounds of copper. By one estimate this would make the Pebble deposit the largest gold resource and the second largest copper resource in North America. This year's work also significantly expanded the higher-grade resources at Pebble to an estimated 435 million tons of material grading 0.84 percent copper.

Ventures Resource focused on gold targets on its Flat property and Donlin Creek North claims. The Donlin Creek North claims abut NovaGold/Placer Dome's Donlin Creek deposit. The drilling program included 5,500 feet of NQ core drilling in eight holes at the Golden Apex, Divide, and Golden Hornfels targets. The program was managed by WGM Inc. At the Flat property, drilling was completed at three targets, with drill results including 5 feet of 0.794 ounces of gold per ton at the Divide target and 22 feet of 0.089 ounces of gold per ton at the Golden Apex target.

TNR Resources Inc. conducted ground exploration and a regional airborne magnetic survey on the Shotgun property covering the area of interest under TNR's new option agreement with NovaGold Resources. Targets identified 
through this work will be advanced and drilled in 2004 along with additional definition drilling on the existing Mose deposit. Several priority exploration targets with similar geophysical and geochemical signatures to the Donlin Creek gold deposits have been identified on the property. The company has an option to earn up to a 50 percent interest from NovaGold in the Shotgun project by spending \$3 million on exploration over the next 4 years to advance the project toward a production decision.

Geocom entered into an agreement with TNR Resources Inc. to earn a 75 percent interest in TNR's option to earn a 70 percent interest in BHP Minerals International Exploration Inc.'s Iliamna Project approximately 60 miles southeast of the Shotgun gold prospect. Upon accomplishing its earnin obligations, Geocom will hold a net 52.5 percent interest in the Iliamna project. To earn its interest, Geocom must expend $\$ 500,000$ prior to September 26, 2004. The interest earned is subject to a back-in right held by BHP to reacquire a 70 percent interest in the project with obligation to fund the project through a formal feasibility study. BHP can earn an additional 10 percent interest by agreeing to arrange the financing necessary to bring the project into commercial production.

The Iliamna project area covers one of three major geophysical anomalies, first identified by BHP in a regional exploration program in 2000. The magnetic geophysical anomaly on the Iliamna project is part of a defined system that stretches over more than 200 square miles. Geocom conducted geologic mapping and geochemical sampling to substantiate the geophysical anomaly followed by a coredrilling program. Additional on-ground geophysical work at the Iliamna project confirmed and further delineated several targets within the sub-regional airborne magnetic anomaly. Because younger, unmineralized rocks cover the Iliamna area, there were no geological or geochemical data available, and the geophysical results are the only guide for the initial exploration drilling. At the " $\mathrm{H}$ " claims, drill hole IL-03-H-01 encountered bedrock at 200-foot depth, and was drilled to a final depth of 686 feet. Bedrock is a very fine-grained metamorphic rock, which is host to fracture-controlled and disseminated sulfides consisting of chalcopyrite, pyrrhotite, and traces of molybdenite. Drill hole IL-03-H-02 was drilled about 0.6 miles southwest of the first hole, and encountered quartz diorite intrusive rock at 278 feet, which continued to a total depth of 837 feet. The plutonic rock contains disseminated and fracture-controlled chalcopyrite, pyrrhotite, and pyrite as well as fracture-controlled chalcopyrite. Each of these two drill holes ended in a mineralized zone, with weak gold and copper mineralization over 550 feet. Geocom and TNR believe that the large intervals of copper-gold mineralization in both the intrusive and metamorphic rocks indicate the potential for a large mineralized system and an excellent exploration target for Donlin Creek and Pebble-type deposits.

\section{Southeastern Region}

Pacific North West Capital, Freegold Ventures, and Lonmin PLC announced discovery of the potentially significant new platinum-bearing Continental zone on the Union Bay project near Ketchikan. Drilling encountered a 3.8-foot zone assaying 0.27 ounces per ton platinum and five other platinum-bearing zones.

Kennecott Minerals Co. continued exploration to expand ore zones at the Greens Creek Mine and found significant polymetallic mineralization across a fault thought to truncate the large orebody. Drilling of exploration targets on the west side of the Gallagher fault produced interesting results. The most significant find was a 10.3foot drill interval that assayed more than 45 ounces of silver per ton. The intercept is across the Gallagher fault, an area that has never been mined or explored before. This intercept increases the probability of finding a continuation of the orebody on the other side of the fault, which could add significant mine life to this already long-lived resource.

Bravo Venture Group completed a joint-venture agreement with property owner Olympic Resources Group and discovered new volcanogenic massive-sulfide mineralization at the Mad Dog prospect and drilled the Lost Lake prospect on Woewodski Island. Several of the six diamond drill holes, totaling 1,484 feet at the Lost Lake prospect, intersected Greens Creek style volcanogenic massive-sulfide mineralization. Semi-massive and massive sphalerite, galena, and silver occur in a bleached, sericite-altered tuff unit sandwiched between andesitic/basaltic tuff, flow, and agglomerate units of Triassic age. The best intercepts from the 2003 drilling are 6 feet of 6.34 percent lead, 16.15 percent zinc, and 7.8 ounces silver per ton; and 4.5 feet of 0.2 percent lead, 18.80 percent zinc, and 1.8 ounces silver per ton.

Century Mining Corp. entered into an agreement to acquire a 100 percent interest in ten non-contiguous properties located in the Juneau Gold Belt. Properties include claims surrounding the Treadwell Mine at Douglas, the Eagle River mine north of Juneau, and claims near Sweetheart Lake. Century also staked claims in anticipation of exploration projects on these properties in 2004.

\section{DEVELOPMENT}

Reported and estimated 2003 mine development expenditures totaled $\$ 15.9$ million, a sharp decrease from $\$ 33.5$ million reported in 2002. Development activity was reported at Greens Creek silver-zinc-gold-lead mine and the Kensington gold project in southeastern Alaska, the Donlin Creek gold project in the southwestern region, the Pogo gold project in the eastern interior, Rock Creek on the Seward Peninsula, and the Nolan Creek placer gold project in northern Alaska. No development occurred at the Red Dog zinc-lead-silver mine in northwestern Alaska due to depressed zinc prices. 
Coeur Alaska completed a final pre-feasibility study for its Kensington gold project 45 miles north of Juneau, Alaska. The deposit contains a "proven and probable reserve" of 1.0 million ounces gold and mineralized material totaling 7.4 million tons at 0.16 ounces gold per ton. Coeur plans a production rate of 100,000 ounces gold per annum at a cash operating cost of about $\$ 195$ per ounce. The capital cost is estimated at $\$ 75$ million. Coeur expects to receive all major permits by June 2004 .

The Donlin Creek gold project dominated the Alaskan exploration scene over the past several years. The 25-million-ounce gold resource, including 11 million ounces measured and indicated, is the largest undeveloped gold resource in North America and the 22nd largest in the world. Placer Dome Inc. exercised its back-in right to earn an additional 40 percent for a total of 70 percent ownership of the Donlin Creek project, and consequently must spend \$32 million, complete a feasibility study, and make a positive construction decision for a mine that would produce at least 600,000 ounces of gold per annum. Work in 2003 focused on identifying acceptable alternatives for project access, power supply, and local sources of key consumables. Plans for 2004 include additional test work to further refine the flow sheet, completion of a pre-feasibility study, and continuing the environmental baseline studies required for permitting. Pending a positive pre-feasibility assessment, the permitting process would begin in the fourth quarter of 2004 and run concurrently with the development of the final feasibility study. The project budget for 2004 is \$6 million.

The Teck Cominco-Sumitomo joint venture conducted permitting, environmental baseline studies, mine plan design, and final feasibility studies at its high-grade Pogo gold project northeast of Delta Junction. The latest mining reserve is 7.7 million tons at a grade of 0.426 ounces gold per ton for 3.28 million ounces gold. The project received a favorable Environmental Impact Statement within 3 years and 1 month of initiating the EIS process, an impressive achievement considering that about 16 months were needed to accommodate a design change from shaft to decline access. All of the key State permits required to begin development of this $\$ 250$ million underground mine complex were issued by December 18, 2003. The U.S. Army Corps of Engineers issued a wetland permit on January 12, 2004. The only major permit not yet issued is EPA's National Pollution Discharge Elimination System (NPDES) permit, expected in the first quarter of 2004. A winter road was completed to the mine site from the Alaska Highway in late January 2004 and construction will commence upon receipt of the NPDES permit. Contracts for construction of the 50-mile access road, the power line, and site preparation have been tendered and are being awarded subject to receipt of the EPA permit. Operating partner, Teck Cominco, anticipates the first gold pour by the end of 2005.

Nova Gold Resources elevated the 1.1-million-ounce Rock Creek gold property near Nome to the development phase in 2003. The program included 30,000 feet of core drilling, and engineering and environmental studies. Nova Gold envisions production in 2005 at a rate of 100,000 ounces gold per year at a total cash cost per ounce of less than $\$ 200$ based on a gold price of $\$ 325$ per ounce. The capital cost is estimated at about $\$ 40$ million.

Silverado completed 3,340 feet of underground development at its Nolan Creek placer gold mine near Wiseman.

\section{PRODUCTION}

A preliminary estimate for the value of mineral production in Alaska during 200 is $\$ 987$ million, including $\$ 849$ million for metals (gold, silver, copper, lead, and zinc), \$38 million for coal, and \$100 million for industrial minerals and materials. This is a year-over-year decrease of about $\$ 26$ million or 3 percent, but, with more complete data, 2003 mineral production value is expected to at least equal last year's value. Table 4 shows the estimated mineral production for 2001 through 2003. Significant production sites are shown in figure 2.

Teck Cominco-NANA's Red Dog Mine near Kotzebue in northwestern Alaska dominated Alaska's mineral production. Red Dog, the largest zinc producer in the world, accounts for nearly 50 percent of the annual value of Alaska's mineral industry. The mill processed 3,474,300 tons with an average grade of 21.7 percent zinc. This 12,300-ton decrease compared to 2002 was caused by fourth-quarter mill maintenance. Sulfide concentrates contained 638,700 tons of zinc, 137,700 tons of lead, and an estimated 6.75 million ounces of silver. Red Dog reported an operating profit of $\$ 59$ million compared to a loss of $\$ 28$ million in 2002 . The improved results are attributed to higher average zinc prices ( $\$ 0.38$ vs $\$ 0.35$ per pound) and greater zinc and lead sales in response to global economic expansion.

Greens Creek Mine, a Kennecott Minerals-Hecla Mining joint venture in southeastern Alaska, is a polymetallic mine (silver-zinc, gold, lead, and copper) and one of the largest silver producers in the world. It produces a silvergold doré and sulfide concentrates containing zinc, lead, and minor copper. The mine achieved another record year, milling 782,100 tons or a 6.5 percent increase over the 2002 record. The average silver head grade was 19.73 ounces silver per ton. Metal production totaled 11,709,400 ounces silver, 99,500 ounces gold, 76,700 tons of zinc, 27,900 tons of lead, and an estimated 1,500 tons of copper. Total cash cost per ounce of silver produced net of gold credits was $\$ 1.18$ per ounce compared to an average 2003 silver price of $\$ 4.88$ per ounce. Significantly, completion of the EIS and supporting state and federal permit 
Table 4. Estimated mineral production in Alaska, 2001-2003 ${ }^{a}$

\begin{tabular}{|c|c|c|c|c|c|c|}
\hline \multirow[b]{2}{*}{ Metals } & \multicolumn{3}{|c|}{ Quantity } & \multicolumn{3}{|c|}{ Estimated values $^{b}$} \\
\hline & 2001 & 2002 & 2003 & 2001 & 2002 & 2003 \\
\hline Gold (ounces) & 550,644 & 562,094 & $528,044^{\mathrm{c}}$ & $\$ 149,246,000$ & $\$ 174,283,000$ & $\$ 191,986,000$ \\
\hline Silver (ounces) & $16,798,000$ & $17,858,183$ & $18,601,089$ & $73,408,000$ & $82,326,000$ & $90,773,000$ \\
\hline Copper (tons) & 1,400 & 1,600 & 1,500 & $1,988,000$ & $2,272,000$ & $2,430,000$ \\
\hline Lead (tons) & 127,385 & 146,462 & 165,686 & $56,049,000$ & $61,514,000$ & $70,094,000$ \\
\hline Zinc (tons) & 634,883 & 718,106 & 715,429 & $507,907,000$ & $502,674,000$ & $486,916,000$ \\
\hline Subtotal & & & & $\$ 788,598,000$ & $\$ 823,069,000$ & $\$ 842,199,000$ \\
\hline \multicolumn{7}{|l|}{ Industrial minerals } \\
\hline Jade and soapstone (tons) & 2.0 & 2.0 & 2.0 & 25,000 & 25,000 & 25,000 \\
\hline Sand and gravel (million tons) & 10.4 & 22.4 & 11.0 & $55,221,000$ & $120,698,000$ & $80,000,000$ \\
\hline Rock (million tons) & 3.1 & 3.2 & 3.0 & $27,176,000$ & $31,442,000$ & $19,975,000$ \\
\hline Subtotal & & & & $\$ 82,422,000$ & $\$ 152,165,000$ & $\$ 100,000,000$ \\
\hline \multicolumn{7}{|l|}{ Energy minerals } \\
\hline Coal (tons) & $1,537,000$ & $1,158,000$ & $1,085,000$ & $\$ 48,108,000$ & $\$ 37,400,000$ & $\$ 37,975,000$ \\
\hline Peat (cubic yards) & 36,000 & 35,000 & 30,000 & 180,000 & 175,000 & 175,000 \\
\hline Subtotal & & & & $\$ 48,288,000$ & $\$ 37, \mathbf{5 7 5 , 0 0 0}$ & $\$ 38,150,000$ \\
\hline TOTAL & & & & $\$ 919,308,000$ & $\$ 1,012,809,000$ & $\$ 980,349,000$ \\
\hline
\end{tabular}

aProduction data from DGGS questionnaires, phone interviews with mine and quarry operators, Alaska Department of Transportation and Public Facilities, and federal land management agencies.

${ }^{\mathrm{b}}$ Values for selected metal production based on average prices for each year; for 2003 - gold ( $\$ 363.58$ /ounce unless other value provided by operator); silver (\$4.88/ounce); copper $(\$ 0.81 / \mathrm{lb})$; zinc $(\$ 0.38 / \mathrm{lb})$; lead $(\$ 0.23 / \mathrm{lb})$. All other values provided by mine operators. Values rounded to nearest $\$ 1,000$.

${ }^{\mathrm{c}}$ Hardrock gold 505,044 ounces, placer gold 23,000 ounces.

Figure 2. Selected significant production sites in Alaska, 2003.

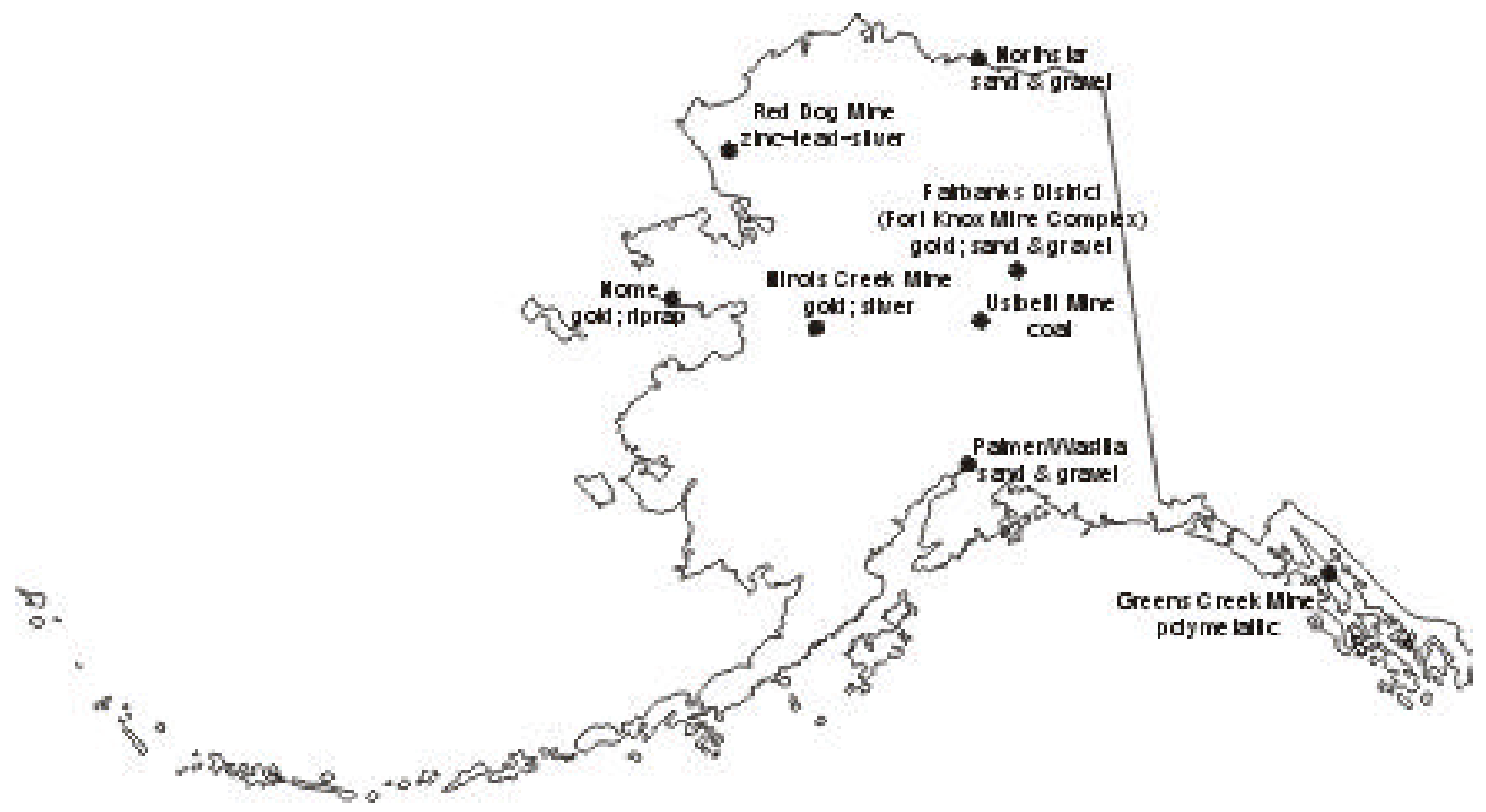


requirements for the Greens Creek tailings expansion will allow continuation of operations at this world-class mine for many more years.

Fort Knox Mine, Alaska's only major hardrock gold mine, operated by Fairbanks Gold Mining Inc. (FGMI), a subsidiary of Kinross Gold Corp., produced about 392,000 ounces of gold in 2003, or about 5 percent less than last year. The ounce shortfall was due primarily to lower gold recovery caused by slightly refractory sulfidic material from deeper, less oxidized zones at True North. The metallurgical properties of True North ore will remain the same until mining at the satellite deposit ceases in early 2005 . FGMI mined 16,015,500 tons of ore, including 13,168,400 tons of mill and low grade ore from the Fort Knox pit and $2,847,100$ tons of mill ore from the True North pit. The mill processed 15,084,700 tons at an average head grade of 0.031 ounces gold per ton.

Usibelli Coal Mine marked its 60th year of operation with a celebration attended by more than 1,200 people. Approximately 68 full-time-equivalent employees produced 1,085,000 tons of coal, 6 percent less than in 2002. The mine supplies six power plants in interior Alaska as well as exports to Korea through the port of Seward. A new 2-year 400,000-tons-per-year contract allowed resumption of shipments to South Korea as well as some rehiring during the fourth quarter. The company continued mining the Two Bull Ridge pit and reclaiming the Poker Flats pit during 2003.

Production data is sketchy at this juncture, but placer gold mine production is expected to increase slightly to about 23,000 ounces this year while sand, gravel, and rock production may see a moderate decrease with declining North Slope oil and gas activity and reduced statewide infrastructure projects.

\section{DRILLING}

Tables 5 and 6 summarize the drilling activity in the state during 2002 by region and type of drilling. Drilling was conducted during all phases of mining (exploration, development, and production) on various projects across Alaska during 2003. Preliminary drilling totals for 2003 are 274,757 feet of core drilling and 116,375 feet of reverse-circulation drilling. Hardrock core (sometimes referred to as hardrock diamond drilling) footage in 2003 is approximately 71 percent of the 385,290 feet reported drilled in 2002. Reverse-circulation drilling footage increased approximately 12 percent from the 103,612 feet reported drilled in 2002. Hardrock core footage for 2003 is approximately 40 percent lower than the average core footage reported in Alaska from 1996 to 2002. Reverse-circulation drilling footage for 2003 is 9 percent higher than the average reverse-circulation drilling footage from 1996 to 2002. Drilling at placer mines was largely unreported for 2003, with 1,400 feet reported to date. The only coal drilling in Alaska occurred at Usibelli Coal Mine.

Significant blasthole drilling occurred at Alaska's lode mines, specifically, the Fort Knox Mine complex (Fort Knox and True North Mines), Red Dog Mine, and Greens Creek Mine. The eastern interior region had the most drilling of all Alaska regions, with 56 percent of the total for 2002. The southwestern region had 27 percent of the drilling, followed by the western region with 12 percent. Major drill programs were conducted by NovaGold Resources Inc. at the Rock Creek deposit, by Northern Dynasty Minerals Ltd. at the Pebble property, by Kinross Gold Corp. in the Fairbanks mining district including Fort Knox and True North mines, by Teck Pogo Inc. at the Pogo property, by AngloGold Inc. at several properties in the eastern interior region, Western Warrior Resources Inc. at the Cliff

Table 5. Drilling footage by region in Alaska, 2003

\begin{tabular}{|c|c|c|c|c|c|c|c|}
\hline Type of drilling & Northern & Western & $\begin{array}{l}\text { Eastern } \\
\text { interior }\end{array}$ & $\begin{array}{l}\text { South- } \\
\text { central }\end{array}$ & $\begin{array}{c}\text { South- } \\
\text { western }\end{array}$ & $\begin{array}{l}\text { South- } \\
\text { eastern }\end{array}$ & TOTAL \\
\hline Placer subtotal & -- & - & 1,400 & -- & -- & -- & 1,400 \\
\hline Coal subtotal & -- & -- & 2,000 & -- & -- & -- & 2,000 \\
\hline Hardrock core & -- & 35,000 & 48,433 & 5,540 & 79,810 & 105,974 & 274,757 \\
\hline Hardrock rotary & -- & - - & 116,375 & -- & - & -- & 116,375 \\
\hline Hardrock subtotal & -- & 35,000 & 164,808 & 5,540 & 79,810 & 105,974 & 294,132 \\
\hline TOTAL (feet) & -- & 35,000 & 168,208 & 5,540 & 79,810 & 105,974 & 394,532 \\
\hline
\end{tabular}

- - = Not reported.

Note: 2,600,000 feet of blasthole drilling reported (incomplete). Drill footages do not include sand and gravel drilling. 
Table 6. Drilling footage reported in Alaska, 1982-2003

\begin{tabular}{|c|c|c|c|c|c|c|c|c|}
\hline Year & $\begin{array}{c}\text { Placer } \\
\text { Exploration }\end{array}$ & $\begin{array}{c}\text { Placer } \\
\text { Thawing }\end{array}$ & $\begin{array}{c}\text { TOTAL } \\
\text { PLACER }\end{array}$ & $\begin{array}{c}\text { TOTAL } \\
\text { COAL }\end{array}$ & $\begin{array}{c}\text { TOTAL } \\
\text { HARDROCK }\end{array}$ & $\begin{array}{c}\text { Hardrock } \\
\text { Core }^{\mathbf{a}}\end{array}$ & $\begin{array}{c}\text { Hardrock } \\
\text { Rotary }^{\mathbf{a}}\end{array}$ & $\begin{array}{c}\text { TOTAL } \\
\text { FEET }\end{array}$ \\
\hline 1982 & 30,000 & 94,000 & 124,000 & 80,000 & 200,000 & -- & -- & 404,000 \\
\hline 1983 & 23,000 & 30,000 & 53,000 & 12,000 & 180,500 & -- & -- & 245,500 \\
\hline 1984 & 31,000 & 98,000 & 129,000 & 25,700 & 176,000 & -- & -- & 330,700 \\
\hline 1985 & 46,000 & 34,000 & 80,000 & 8,700 & 131,700 & -- & -- & 220,400 \\
\hline 1986 & 32,400 & 227,000 & 259,400 & 28,800 & 50,200 & -- & -- & 338,400 \\
\hline 1987 & 50,250 & 130,000 & 180,250 & 19,900 & 115,100 & 95,600 & 19,500 & 315,250 \\
\hline 1988 & 152,000 & 300,000 & 452,000 & 26,150 & 353,860 & 223,630 & 130,230 & 832,010 \\
\hline 1989 & 97,250 & 210,000 & 307,250 & 38,670 & 332,230 & 242,440 & 89,790 & 678,150 \\
\hline 1990 & 78,930 & 105,000 & 183,930 & 18,195 & 760,955 & 648,600 & 112,355 & 963,080 \\
\hline 1991 & 51,247 & 130,000 & 181,247 & 16,894 & 316,655 & 205,805 & 110,850 & 514,796 \\
\hline 1992 & 6,740 & 65,000 & 71,740 & 12,875 & 359,834 & 211,812 & 148,022 & 444,449 \\
\hline 1993 & 25,216 & -- & 25,216 & - & 252,315 & 124,325 & 127,990 & $\mathbf{2 7 7 , 5 3 1}$ \\
\hline 1994 & 21,000 & -- & 21,000 & 8,168 & 438,710 & 347,018 & 91,692 & 467,878 \\
\hline 1995 & 27,570 & -- & 27,570 & -- & 415,485 & 363,690 & 51,795 & 443,055 \\
\hline 1996 & 61,780 & - & 61,780 & 8,500 & 658,857 & 524,330 & 134,527 & 729,137 \\
\hline 1997 & 38,980 & -- & 38,980 & 13,998 & 704,510 & 523,676 & 180,834 & 757,488 \\
\hline 1998 & 33,250 & - & 33,250 & 2,300 & 549,618 & 505,408 & 45,670 & 585,168 \\
\hline 1999 & 6,727 & - & 6,727 & - & 448,797 & 369,863 & 78,934 & 455,524 \\
\hline 2000 & 15,480 & - & 15,480 & -- & 546,268 & 418,630 & 127,638 & 561,748 \\
\hline 2001 & 1,100 & -- & 1,100 & 36,151 & 316,068 & 240,318 & 75,750 & 353,319 \\
\hline 2002 & 1,250 & - & 1,250 & - - & 488,902 & 385,290 & 103,612 & 490,152 \\
\hline 2003 & 1,400 & - & 1,400 & 2,000 & 391,132 & 274,757 & 116,375 & 394,532 \\
\hline
\end{tabular}

${ }^{\text {a C}}$ Core and rotary drilling not differentiated prior to 1987.

- - = Not reported.

Note: 2.6M feet of blasthole drilling reported for 2003 (incomplete).

Mine, Geocom Resources Inc. at the Iliamna property, Ventures Resource Alaska/WGM Inc. at the Flat property, Bravo Ventures/Olympic Resources Group LLC on Woewodski Island, and by Kennecott Minerals Co. at Greens Creek Mine.

\section{GOVERNMENT ACTIONS}

The Alaska Division of Geological \& Geophysical Surveys (DGGS) conducted a regional geologic mapping project near Livengood, 75 miles northwest of Fairbanks. Geochemical results from this work were released in January 2004. A draft one-inch to one-mile scale geologic map of the 124-square-mile field area will be published in May 2004. DGGS also released a preliminary geologic map of work conducted in the Salcha River-Pogo geophysical tract within the Big Delta Quadrangle from 2000 to 2002. Geologic mapping and geochemical sampling were conducted across an area from the Salcha River near Caribou Creek to the Goodpaster River drainage near the Pogo gold property.

DGGS released maps and results from a 618-squaremile geophysical survey in the Council area of the Seward Peninsula. Fieldwork including geologic mapping is planned for a portion of the survey area during 2004.
Geophysical surveys funded by the Bureau of Land Management and managed by DGGS were released for the Delta River area (portion of the Denali Block) west of Paxson, and in the Sleetmute area of southwestern Alaska. Existing company data covering 250 square miles were incorporated into the 600-square-mile Delta River survey. The 2003 Sleetmute total field magnetic and electromagnetic survey covers 640 square miles and is adjacent to the 2000 Aniak geophysical survey. BLM conducted extensive mining district studies in regions in and surrounding the survey area.

During 2003, changes to the state permitting process were made with the transfer of the Alaska Coastal Management Program and Division of Habitat to the Department of Natural Resources (DNR). DNR will continue to coordinate the permitting of all mine projects, large and small, and expects to continue improving the cooperative permitting environment.

The Department of Natural Resources issued the final state permits needed for Teck-Pogo Inc.'s Pogo Mine Project on December 18 2003. Teck-Pogo, a wholly owned subsidiary of Teck Cominco Ltd., requested that the State of Alaska authorize the development of the Pogo Mine Project. Teck-Pogo is authorized to begin construction and use of the Shaw Creek and Goodpaster winter trails 
immediately to mobilize equipment and supplies. Because the project requires a water discharge permit from the Environmental Protection Agency (EPA) and a wetlands fill permit from the US Army Corps of Engineers, a Federal Environmental Impact Statement (EIS) was completed. The State of Alaska was a cooperating agency in the EIS process, and has used the EIS to assist in decision making for its authorizations. State agencies involved in these efforts include the departments of Natural Resources, Environmental Conservation, Fish \& Game, Law, and Transportation. A large mine project team has been established with representatives from these agencies to coordinate state permitting activities for the Pogo Gold Project.

DNR also began working as a cooperating agency with the U.S. Forest Service and U.S. Environmental Protection Agency on the necessary permits for the expansion of the Greens Creek tailings facility in southeastern Alaska. This expansion will require the approval of a revised solid waste permit from DEC as well as additional revisions to the financial assurances. Work is in progress to update permits for the Red Dog zinc mine.

DNR gave reclamation awards to several mining operations in 2003. Steve Pomrenke was recognized for outstanding reclamation of 6 years of placer operations on 19 acres of ground on Tripple Creek in the Nome mining district. Outstanding reclamation work was completed by Jim Conway and Sam Turner on Pete's/Bird and Upper Cache Creeks near Petersville in the Yentna mining district. These placer miners completed reclamation work on State mining claims that was not performed by the previous claim owners. Reclamation work included disposing of, by means of burial, several thousand tons of abandoned mining equipment, including large empty fuel tanks and camp structures. Several tons of scrap metal and usable equipment were removed and salvaged. The willingness of these miners to work with agency personnel, and their action in removing and disposing of the abandoned hazards was extremely helpful to the State of Alaska. Betty Krutzsch operated a placer mine on patented mining claims along Specimen Gulch in the Nome mining district for 13 years and completed outstanding reclamation work on 30 acres of ground. Once mining was completed, the disturbed land was recontoured and the stream channel was reconstructed. Mrs. Krutzsch went beyond the minimum reclamation standards by hand seeding and fertilizing the area, as well as planting willow stakes and live willows.

The conveyance of the eastern portion of the Denali Block from the federal government to state ownership was completed in January. This area, near the junction of the Denali and Richardson highways, has high potential for the discovery of platinum-group metals and other valuable mineral resources.
The U.S. Geological Survey (USGS), in cooperation with other agencies, initiated a 5-year project titled "Tintina metallogenic province integrated studies on geological framework, mineral resources, and environmental signatures." Fieldwork began with studies of the Black Mountain-Tibbs Creek area of the Big Delta B-1 Quadrangle, including geologic mapping, and baseline geochemistry and biogeochemistry studies.

The USGS and BLM continued a number of cooperative projects under the Minerals Data and Information Rescue in Alaska (MDIRA) program. The USGS continued compiling non-rock and lithochemical data scheduled for release in late 2003. The USGS and DGGS continued work on the Alaska Resource Database Files (ARDF) project. Other DGGS-managed, MDIRA-funded projects include compilation of Alaskan bedrock and surficial geology map index project, compilation of DGGS lithochemical data, scanning of USGS bulletins and professional papers dealing with Alaska and providing versions of those documents for public access on the Web, and building a comprehensive database system at DGGS. Other MDIRA-funded projects are in progress at other divisions of DNR, the University of Alaska Fairbanks, and with private contractors.

The Bureau of Land Management conducted an extensive field program in the Delta River mining district of eastern and southcentral Alaska. Lode, placer, industrial, and coal sites were visited and geochemical samples were collected and the analytical results were published. BLM plans to conduct another year of fieldwork and possibly acquire more airborne geophysical data in this area.

\section{OUTLOOK}

The 2004 outlook is positive for Alaska's mining industry. Increased metal prices will improve the bottom line for Alaska's metal producers and increase funds available for exploration. Construction of the Pogo Mine by Teck Cominco Ltd., to begin in early 2004, is also expected to spur increased mineral exploration in interior Alaska. Six lode mine projects are also in the development phase, and new gold production is expected by early 2005 .

Claim staking increased almost twofold on State lands in 2003 compared to the last several years. Significant staking occurred in the Pogo area of eastern Alaska, in the Alaska Range near Paxson in the southcentral region, and in the area surrounding the Pebble property in southwestern Alaska. Exploration expenditures should increase in these large claim areas due to subsequent field geological and geochemical studies in 2004 and beyond.

Alaska remains an exploration frontier, and recent world-class discoveries make Alaska a global exploration priority. Alaska's major mines are showcase examples of modern mining and demonstrate that the Alaskan mining industry is globally competitive, and is poised to become a major player in worldwide commodities markets. 
Front Cover. Pete Nyren, assisted by Shawn Sell, cutting channel samples with a Partner portable rock saw in the Jaguar zone wehrlite of the Union Bay Alaskan-type ultramafic complex to test lateral continuity of secondary magnetite-hosted PGE mineralization. Photo provided by Chris Van Treeck.

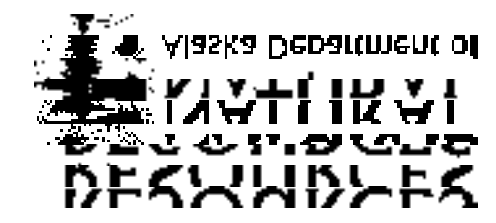

DEPARTMENT OF NATURAL RESOURCES

Division of Geological \& Geophysical Surveys

http://www.dggs.dnr.state.ak.us

DEPARTMENT OF COMMUNITY \& ECONOMIC DEVELOPMENT

Division of Community \& Business Development

http://www.dced.state.ak.us/trade/

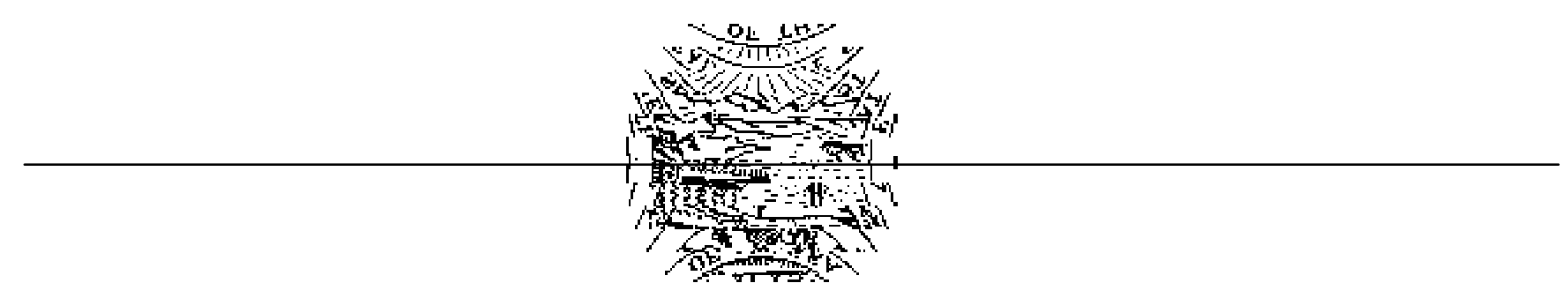

